\title{
Evaluation of nutritional, color and volatiles properties of currant (Ribes spp.) cultivars in Turkey
}

\author{
Hacer EKSI KARAAGAC ${ }^{1,2 *}$ (D), Filiz CAVUS ${ }^{1}$, Burcu KADIOGLU ${ }^{1}$, Nagihan UGUR ${ }^{1}$, Emre TOKAT ${ }^{1}$, \\ Yasemin SAHAN ${ }^{3}$
}

\begin{abstract}
In this study, the properties of nutritional, color and volatile organic compounds of currant varieties (Ribes spp.) in Turkey were investigated. A total of 125 different volatile organic compounds were identified with GC-QTOF/MS. The levels of protein, sugar fractions, dietary fibre, ascorbic acid and minerals of the currant fruits were found to be different between varieties. Ascorbic acid content ranged from 169.33 to $725.52 \mathrm{mg} / 100 \mathrm{~g}$ dry weight. The $\mathrm{K}, \mathrm{Ca}$ and $\mathrm{Mg}$ minerals were found to be in high amount in all varieties. Total dietary fibre levels were found between 7.17 (Red Lake) and $9.90 \mathrm{~g} / 100 \mathrm{~g} \mathrm{dw}$ (Rosenthal). The common volatiles found in all cultivars were ocimene, carene, alpha-phellandrene, alpha-terpinene, benzaldehyde and piperonal. 'Rosenthal' and 'Goliath' displayed large differences in the volatile fraction which allow for their discrimination in the PCA (principal component analysis) plot.
\end{abstract}

Keywords: Ribes; volatile; ascorbic acid; chemical; currant.

Practical Application: Determination of nutritional, color and volatile compounds of currant cultivars.

\section{Introduction}

Currants (Ribes spp.), which belong to Grossulariaceae family, are known to have a strong, characteristic aroma and are considered an excellent source of vitamin C (Stewart, 1996; Mikulic-Petkovsek et al., 2015). Currants are perennial small shrubby bushes widely cultivated in cool temperature areas (Garcia et al., 2012). Currants are consumed as fresh fruit and processed into currant products. In the production of blackcurrant products their strong and characteristic aroma is important (Kampuss et al., 2008). Also, currant extracts are used in the food industry as coloring agent and flavorant (Hollands et al., 2008).

Aroma is a complex mixture of volatile organic compounds, which has an important impact on the overall flavor of fruits (Baldwin, 2002) and play a major role in determining the perception and acceptability of foods by consumers (Garcia et al., 2012; Villatoro et al., 2008). Overall, aroma is basically comprised of volatile compounds in fruits, and volatile profile in fruits is essentially determined by fruit genotype and cultivation conditions (Liu et al., 2018). Volatile organic compounds of currant fruits are composed of a complex mixture of aldehydes, ketones, terpenes, terpenoids, alcohols and esters (Varming et al., 2006; Piry \& Pribela, 1994; Christensen \& Pedersen, 2006). Fresh edible Ribes fruits are promising crops with high economic value, not only due to their desired taste and nutritional value but also for their known health-promoting properties (Mikulic-Petkovsek et al., 2015). Contents of vitamin $C$ in currant berries is 4-5 times higher than in citrus fruits known as a source of ascorbic acid.
(Burak \& Güngör, 2001; Mikkonen et al., 2001; Varming et al., 2004; Bordonaba \& Terry, 2008).

Currant cultivation is not common in Turkey, however, due to their different tastes and aromas, interest in breeding of currant has increased in recent years. 'Boskoop Giant,' 'Rosenthal', 'Goliath', 'Red Lake' and complex-cross fruit 'Jostaberry' (hybrid of blackcurrant and gooseberry) are some of the currant varieties which are grown in Turkey. Nowadays, research focuses primarily on the chemical, morphological and pomological properties of currants; however, no study has been made on volatile organic components in currant species in Turkey. The aim of this study was to identify and compare volatile compounds as well as their nutritional and color properties of 5 currant cultivars.

\section{Materials and methods}

\subsection{Material}

Black currant fruits (R. Nigrum L. cv. 'Boskoop Giant', 'Rosenthal,' 'Goliath'); red currant fruit (R. Rubrum L. cv. 'Red Lake') and complex-cross fruit (R. Nidigrolaria L. cv. 'Jostaberry') were harvested from Bursa, Turkey, in July 2017. Healthy fruits were harvested at commercial ripening for each cultivar. The harvested fruits were immediately transferred to laboratory and then fruits were prepared for the analysis of volatile organic compounds. In addition, color, $\mathrm{pH}$, moisture, ascorbic acid, titratable acid, and total soluble solids in these currant cultivars after harvest 
were immediately measured. The whole currant samples were frozen at $-80{ }^{\circ} \mathrm{C}$ before further analyses.

\subsection{Methods}

\section{Physico-chemical, chemical and nutritional compound analysis}

Moisture, total soluble solids, titratable acidity and $\mathrm{pH}$ contents of fruits were determined according to TS 1129 ISO 1026 (TSE, 1998), AOAC Official Method 932.12 (Association of Official Analytical Chemists, 2000b), AOAC Official Method 942.15 (Association of Official Analytical Chemists, 2000a) and TS 1728 ISO 1842, respectively (TSE, 2001). The amount of protein in fruit samples was measured by using LECO FP-528 instrument according to AOAC 990.03 (Association of Official Analytical Chemists, 2002) Combustion Method. The protein content of currant fruits was calculated using 6.25 as nitrogen to protein conversion factor.

Sugar content was obtained by HPLC according to AOAC Official Method 977.20 (Association of Official Analytical Chemists, 2000c). A solid-liquid extraction procedure was used in samples. $10 \mu \mathrm{L}$ of extract was injected onto a HPLC (Shimadzu Corp., Kyoto, Japan) system equipped with Shodex Asahipak NH2P-50 4 E column $(5 \mu \mathrm{m}, 250 \times 4.6 \mathrm{~mm}$, Munich, GERMANY) and a refractive index (RI) detector. The chromatographic separation was achieved using an isocratic elution with acetonitrile/water $(75: 25, \mathrm{v} / \mathrm{v})$ at a flow rate of $1.0 \mathrm{ml} / \mathrm{min}$. The column was maintained at $30^{\circ} \mathrm{C}$.

Sodium $(\mathrm{Na})$, calcium $(\mathrm{Ca})$, iron $(\mathrm{Fe})$, potassium $(\mathrm{K})$, magnesium $(\mathrm{Mg})$, manganese $(\mathrm{Mn})$, copper $(\mathrm{Cu})$, zinc $(\mathrm{Zn})$, selenium (Se) content of fruit samples were analysed by Agilent 7500 CX ICP/MS according to NMKL 186 (Nordic Committee on Food Analysis, 2007). A closed microwave digestion unit (Berghof speedwave MWS-3, Germany) equipped with 12 Teflon vessels was used to mineralize $0.5 \mathrm{~g}$ of each homogenized sample, to which $6 \mathrm{ml}$ of ultrapure $70 \%$ nitric acid and $1 \mathrm{ml}$ of hydrogen peroxide $30 \%(\mathrm{v} / \mathrm{v})$ were added, in order to determinate the dissolved metals. The sample solution transferred into $50 \mathrm{~mL}$ centrifuge tubes and filled to exact volüme. Then the solution was filtered through a $0.45 \mu \mathrm{m}$ PVDF membrane filter and $15 \mathrm{~mL}$ of filtrated final solution was analyzed.

The extraction and analysis of the ascorbic acid was performed according to Gökmen et al. (2000) with slight modification. Briefly, currant samples were homogenized in a blender (Waring, Torrington, CT) and $20 \mathrm{~g}$ homogenates were diluted in $200 \mathrm{~mL}$ extraction solvent (60 g meta-phosphoric acid dissolved in 1000 $\mathrm{ml}$ distilled water) then sample mix exposured to ultrasonic bath for 20 minutes, then centrifuged (Sigma 3K15, Germany) $15 \mathrm{~min}$ at $5000 \mathrm{rpm}$. The resulting extracts were filtered through $0.45 \mu \mathrm{m}$ hydrophilic PVDF filters (Millipore Millex-HV, Merck) and filtrates was placed in $2 \mathrm{ml}$ amber color vials. Filtrate was analyzed on a HPLC (Agilent 1100 Series, CA, USA) with an chromatography oven at $20^{\circ} \mathrm{C}$ and a UV- diode array detector collecting absorbance data at $244 \mathrm{~nm}$, controlled by OpenLab CDS ChemStation software (Agilent 1100 Series, CA, USA). Twenty microliter filtrate was injected into a HI-5 C18 (5 $\mu \mathrm{m}$, $250 \times 4.6 \mathrm{~mm}$, Hichrom, UK) analytical column. The pump was operated in isocratic mode at $0,6 \mathrm{ml} / \mathrm{min}$ with a mobile phase consisting of; tetrabutylammonium hydrogen sulfate /methanol $(945: 55, \mathrm{v} / \mathrm{v}) \mathrm{pH}$ adjusted to 2.0 and a 5 point calibration curve was used to calculate the amount of ascorbic acid in each sample.

Soluble dietary fibre (SDF), insoluble dietary fibre (IDF) and total dietary fibre (TDF) analyses in currant samples were carried out by using $\alpha$-amylase, amyloglucosidase, protease enzymes and MES/TRIS buffer solutions by ANKOM automated dietary fibre analyzer (Ankom Technology, USA) instrument according to AOAC Official Method 991.43 (Association of Official Analytical Chemists, 1994). TDF was the sum of SDF and IDF.

\section{Colour analysis}

Fruit samples color values were measured by Minolta CM-5 spektrofotometer (Minolta, Osaka, Japan) recording $L^{*}, \mathrm{a}^{*}, \mathrm{~b}^{*}$ color coordinates on the berry surface (Konica-Minolta, 2013). Color was determined with the CIE system, in which $L^{*}, a^{*}$ and $b^{*}$ represent darkness-lightness, greenness-redness and blueness-yellowness, respectively. Color values were recorded by calculating the average of reflectance values measured at 3 different points of each fruit.

\section{Analysis of Volatile Organic Compounds (VOCs)}

The manual SPME device (Supelco, Bellafonte, PA, USA) with a fiber precoated of a $100 \mu \mathrm{m}$ thick layer of polydimethyl siloxane (PDMS) was used for extraction of the volatiles. $5 \mathrm{~g}$ of pulp were placed into a $20-\mathrm{mL}$ headspace glass vial, and, after being capped with a screw cap with PTFE/silicone septa (Agilent, USA), the vial was placed into a thermostatic bath at $45^{\circ} \mathrm{C}$ and stirred for $20 \mathrm{~min}$ (equilibration time), at $180 \mathrm{rpm}$. Prior to use, the fiber was placed into the enjection port of the GC-QTOF at $260{ }^{\circ} \mathrm{C}$ for 10 minutes for conditioning. Then the conditioned PDMS fiber was introduced into the vial by manually penetrating the septum and after 45 minutes absorption time, the fiber was retracted and inserted immediately into the injection port of GC-QTOF in splitless mode for desorption of the adsorbed volatile compounds for analysis. The extracted compounds were thermally desorbed at $250{ }^{\circ} \mathrm{C}$ for $3 \mathrm{~min}$. All experiments and sample measurements were carried out in triplicate. The SPME fiber was maintained $10 \mathrm{~mm}$ above the solid samples.

The extract analysis was carried out with an Agilent 7200 Accurate Mass QTOF GC/MS system equipped with a ZB-Wax capillary column ( $30 \mathrm{~m} \times 0.25 \mathrm{~mm}, 0.25 \mu \mathrm{m})$ (Phenomenex, GERMANY). Helium was used as the carrier gas at a constant column flow of $1.2 \mathrm{ml} / \mathrm{min}$. GC oven temperature was kept at $45{ }^{\circ} \mathrm{C}$ for $5 \mathrm{~min}$ and programmed to $180{ }^{\circ} \mathrm{C}$ at a rate of $3{ }^{\circ} \mathrm{C} / \mathrm{min}$, and then programmed to $240^{\circ} \mathrm{C}$ at a rate of $20^{\circ} \mathrm{C} / \mathrm{min}$. The injector temperature was set at $250^{\circ} \mathrm{C}$. Mass spectra were recorded at $70 \mathrm{eV}$ in electron impact (EI) ionization mode. Mass range was from $\mathrm{m} / \mathrm{z} 20$ to $300 \mathrm{amu}$. Identification of the volatile components were carried out by comparing the GC retention times and mass spectra of the samples with the data system of Adams, Flavour and Nist (National Institute of Standards and Technology) Library. For some volatile organic compound, MS identification was confirmed with authentic standards. 


\section{Statistical analysis}

All results were expressed as mean values \pm standard deviation (SD) for six replicates. Statistical analyses were performed with JMP software, v.9.0.2 (SAS, USA). Fisher's LSD test was used to compare the means among treatments with significant differences $(\mathrm{p}<0.01)$. Principal Component Analysis (PCA) of the volatiles of different Ribes cultivars was performed using the Mass Profiler Professional (Agillent version B:13) software.

\section{Results and discussion}

\subsection{Physico-chemical, chemical and nutritional compound analysis}

Significant variations $(\mathrm{p} \leq 0.01)$ in the physico-chemical and chemical properties could be observed between the different varieties (Table 1). These differences might be affected by several factors such as the genetic, maturity and phenotypic differences. Dry matter contents of currant fruits changed significantly depending on variety (Table 1). The highest and lowest levels dry matter content were determined in 'Goliath' $(22.28 \mathrm{~g} / 100 \mathrm{~g})$ and 'Red Lake' (16.76 g/100 g) samples, respectively. According to Mattila et al. (2016), 'Red Lake' and 'Boskoop Giant' contained dry matter $16.9 \pm 0.1$ and $23.2 \pm 1.0$, respectively and dry matter content in black currant cultivars between 19.8-25.9 g/100 g. Woznicki et al. (2015) determined dry matter content in black currants between $12.27-17.63 \mathrm{~g} / 100 \mathrm{~g}$. These results were similar with our results. There were significant differences in soluble solids ( $\mathrm{p} \leq 0.01)$ amoung the currant varieties. 'Rosenthal' (17,03 $\circ$ Brix) and 'Goliath' (16,95 Brix) showed the highest values of soluble solid contents, while the lowest content was recorded in 'Red Lake' (11.92 Brix). In the literature reported that the soluble solid contents in black currant ranged from $13.89 \circ$ Brix (Contessa et al., 2013) to $16.14 \circ$ Brix (Rubinskiene et al., 2005) and between 7.4-10.7 Brix in the red currant varieties (Pantelidis et al., 2007). Titratable acidity and $\mathrm{pH}$ value are important factors determining consumer preference of both sweetness and sourness of fruits. 'Jostaberry' showed the highest titratable acidity values ( $18.05 \mathrm{~g}$ citric acid/100g dw), while the lowest was recorded in 'Goliath'(11.18 g citric acid/100 g dw) varieties amoung the currant samples. Rubinskiene et al. (2005) found that the titratable acidity content in black currant cultivars between $2.33-3.15 \mathrm{~g}$ citric acid/100g fw. These data were paralel with our findings. The $\mathrm{pH}$ levels of currant samples ranged from 2.90 (Jostaberry) to 3.05 (Red Lake) (Table 1), which agrees with the results published by Contessa et al. (2013) and Konić-Ristić et al. (2011). Mikulic-Petkovsek et al. (2015) reported that $\mathrm{pH}$ between 2.62-3.45 in black currant cultivars; 2.86-3.45 in red currant cultivars and 3.05-3.24 in complex-cross fruit Jostaberry in different maturity stages. For 'Rosenthal' variety $\mathrm{pH}$ levels determined 2.98, 2.99, 3.03 in three maturity stages (Mikulic-Petkovsek et al., 2015). Significant differences

Table 1. Physico-chemical, chemical and nutritional composition of currant varieties.

\begin{tabular}{|c|c|c|c|c|c|}
\hline & ROSENTHAL & RED LAKE & BOSKOOP G. & JOSTABERRY & GOLIATH \\
\hline Soluble solids & $17.03 \pm 0.10^{\mathrm{a}}$ & $11.92 \pm 0.06^{\mathrm{d}}$ & $16.70 \pm 0.06^{\mathrm{b}}$ & $14.68 \pm 0.08^{c}$ & $16.95 \pm 0.12^{\mathrm{a}}$ \\
\hline $\mathrm{pH}$ & $2.95 \pm 0.01^{c}$ & $3.05 \pm 0.01^{\mathrm{a}}$ & $2.91 \pm 0.01^{\mathrm{d}}$ & $2.90 \pm 0.01^{\mathrm{e}}$ & $3.0 \pm 0.01^{\mathrm{b}}$ \\
\hline Dry matter & $20.61 \pm 0.33^{\mathrm{b}}$ & $16.76 \pm 0.37^{\mathrm{d}}$ & $20.50 \pm 0.26^{\mathrm{b}}$ & $17.48 \pm 0.67^{c}$ & $22.28 \pm 0.16^{\mathrm{a}}$ \\
\hline Acidity & $15.57 \pm 0.03^{\mathrm{b}}$ & $14.38 \pm 0.02^{c}$ & $15.76 \pm 0.03^{\mathrm{b}}$ & $18.08 \pm 0.03^{\mathrm{a}}$ & $11.18 \pm 0.05^{\mathrm{d}}$ \\
\hline Protein & $3.30 \pm 0.01^{\mathrm{d}}$ & $5.37 \pm 0.02^{\mathrm{a}}$ & $4.10 \pm 0.03^{\mathrm{b}}$ & $4.12 \pm 0.01^{\mathrm{b}}$ & $3.59 \pm 0.04^{c}$ \\
\hline \multicolumn{6}{|l|}{ Sugar fractions } \\
\hline Fructose & $22.61 \pm 0.05^{\mathrm{b}}$ & $21.00 \pm 0.09^{c}$ & $20.98 \pm 0.22^{c}$ & $26.37 \pm 0.09^{\mathrm{a}}$ & $21.95 \pm 0.10^{\mathrm{bc}}$ \\
\hline Glucose & $17.22 \pm 0.08^{c}$ & $18.79 \pm 0.11^{\mathrm{b}}$ & $15.07 \pm 0.29^{\mathrm{d}}$ & $20.94 \pm 0.06^{\mathrm{a}}$ & $17.37 \pm 0.08^{c}$ \\
\hline Sucrose & $1.16 \pm 0.03^{b}$ & Nd. ${ }^{d}$ & $0.78 \pm 0.01^{\mathrm{c}}$ & $1.54 \pm 0.03^{\mathrm{a}}$ & $1.48 \pm 0.05^{\mathrm{a}}$ \\
\hline Total sugars & 40.99 & 39.79 & 36.83 & 48.85 & 40.8 \\
\hline \multicolumn{6}{|l|}{ Dietary fiber } \\
\hline SDF & $7.23 \pm 0.09^{\mathrm{a}}$ & $4.00 \pm 0.08^{c}$ & $7.17 \pm 0.08^{a}$ & $5.55 \pm 0.12^{b}$ & $6.82 \pm 0.14^{\mathrm{a}}$ \\
\hline IDF & $2.67 \pm 0.04^{b}$ & $3.16 \pm 0.04^{\mathrm{a}}$ & $2.34 \pm 0.01^{c}$ & $2.06 \pm 0.03^{\mathrm{d}}$ & $3.05 \pm 0.01^{\mathrm{a}}$ \\
\hline TDF & $9.90 \pm 0.11^{\mathrm{a}}$ & $7.16 \pm 0.10^{\mathrm{b}}$ & $9.51 \pm 0.07^{\mathrm{a}}$ & $7.61 \pm 0.11^{b}$ & $9.87 \pm 0.17^{\mathrm{a}}$ \\
\hline Ascorbic acid & $725.52 \pm 1.36^{\mathrm{a}}$ & $169.33 \pm 0.70^{\mathrm{d}}$ & $582.39 \pm 3.21^{\mathrm{b}}$ & $591.42 \pm 2.92^{\mathrm{b}}$ & $495.64 \pm 4.16^{c}$ \\
\hline \multicolumn{6}{|l|}{ Minerals } \\
\hline $\mathrm{Na}$ & Nd. & Nd. & Nd. & Nd. & $11.58 \pm 0.10^{\mathrm{a}}$ \\
\hline $\mathrm{Mg}$ & $666.13 \pm 6.52^{\mathrm{ab}}$ & $571.24 \pm 3.61^{c}$ & $684.63 \pm 7.71^{\mathrm{a}}$ & $622.08 \pm 4.61^{b c}$ & $665.22 \pm 9.43^{\mathrm{ab}}$ \\
\hline $\mathrm{K}$ & $9,268.51 \pm 94.49^{\mathrm{cd}}$ & $10,205.91 \pm 103.71^{\mathrm{ab}}$ & $8,374.78 \pm 103.29^{d}$ & $9,824.03 \pm 87.37^{b c}$ & $10,803.9 \pm 164.34$ \\
\hline $\mathrm{Ca}$ & $1,447.55 \pm 16.76^{c}$ & $1,235.14 \pm 17.38^{\mathrm{d}}$ & $1,673.22 \pm 12.91^{\mathrm{b}}$ & $1,815.45 \pm 17.88^{\mathrm{a}}$ & $1,051.84 \pm 11.51^{\mathrm{e}}$ \\
\hline $\mathrm{Mn}$ & $4.85 \pm 0.02^{c}$ & $5.37 \pm 0.03^{b}$ & $5.46 \pm 0.04^{\mathrm{b}}$ & $5.89 \pm 0.03^{\mathrm{a}}$ & $5.61 \pm 0.06^{\mathrm{ab}}$ \\
\hline $\mathrm{Fe}$ & $28.14 \pm 0.56^{\mathrm{b}}$ & $36.40 \pm 0.32^{\mathrm{a}}$ & $33.46 \pm 0.22^{\mathrm{a}}$ & $25.57 \pm 0.40^{\mathrm{bc}}$ & $22.58 \pm 0.32^{c}$ \\
\hline $\mathrm{Cu}$ & $4.03 \pm 0.07^{c}$ & $9.61 \pm 0.07^{b}$ & $11.51 \pm 0.17^{\mathrm{a}}$ & $3.83 \pm 0.03^{c}$ & $4.49 \pm 0.12^{c}$ \\
\hline $\mathrm{Zn}$ & $4.71 \pm 0.09^{b}$ & $7.16 \pm 0.10^{\mathrm{a}}$ & $7.51 \pm 0.16^{\mathrm{a}}$ & $4.46 \pm 0.06^{\mathrm{b}}$ & $4.76 \pm 0.16^{\mathrm{b}}$ \\
\hline $\mathrm{Se}$ & Nd. & Nd. & Nd. & Nd. & Nd. \\
\hline
\end{tabular}

Means \pm standard deviations; values were expressed as ${ }^{\circ}$ Brix for soluble solids, g/100 g for dry matter, $g$ citric acid/100 g dry weight for titratable acidity, g/100 g dry weight for protein, $\mathrm{g} / 100 \mathrm{~g}$ dry weight for sugar fractions, g/100 g dry weight for dietary fiber, $\mathrm{mg} / 100 \mathrm{~g}$ dry weight for ascorbic acid and $\mathrm{mg} / \mathrm{kg}$ dry weight for minerals. Different letters in the same lines represent results with statistical difference, according to the Fisher's LSD test ( $\mathrm{p} \leq 0.01)$; Nd.: Not detected. 
in protein content among the different species were recorded $(\mathrm{p} \leq 0.01)$ (Table 1). 'Red Lake' (5.37 g/100 g dw) showed the highest amount of protein, while the lowest content was recorded in 'Rosenthal' ( $3.30 \mathrm{~g} / 100 \mathrm{~g} \mathrm{dw}$ ) variety. As expected, protein contents were relatively low in all fruits. No data are available in the literature for currant berries. But, the protein content of currant berries were found to be high as compared to wild raspberries (Fu et al. 2015). Souza et al. (2014) determined protein content in blackberry $1.27 \mathrm{~g} / 100 \mathrm{~g} \mathrm{fw}$, in red raspberry $1.0 \mathrm{~g} / 100 \mathrm{~g} \mathrm{fw}$, in strawberry $0.5 \mathrm{~g} / 100 \mathrm{~g} \mathrm{fw}$, in blueberry $0.48 \mathrm{~g} / 100 \mathrm{~g}$ fw and in cherry fruits $1.0 \mathrm{~g} / 100 \mathrm{~g} \mathrm{fw}$. In general, the currant berries showed similar protein content with other berry fruits.

Individual sugars were quantified in different cultivars of red currant, black currants and Jostaberry (Table 1). The main sugars in analysed Ribes species were glucose, fructose and sucrose. The average amount of fructose varied from 21.0 to $26.37 \mathrm{~g} / 100 \mathrm{~g} \mathrm{dw}$ and average amount of glucose varied from 15.07 to $20.94 \mathrm{~g} / 100 \mathrm{~g} \mathrm{dw}$. Significant differences in each sugar fraction content among the different species were recorded. 'Jostaberry' contained highest levels of fructose $(26.37 \mathrm{~g} / 100 \mathrm{~g} \mathrm{dw})$, glucose $(20.94 \mathrm{~g} / 100 \mathrm{~g} \mathrm{dw})$ and sucrose $(1.54 \mathrm{~g} / 100 \mathrm{~g} \mathrm{dw})$. However, 'Boskoop Giant' which is the black currant varieties was characterised by lowest levels of these sugars. In terms of total sugars, our findings are paralel with Mikulic-Petkovsek et al. (2015) reported for other 'Rosenthal' variety (5.07-11.83 g/ $100 \mathrm{~g} \mathrm{fw}$ ) and 'Jostaberry' (5.75-10.05 g/100 g fw). In general, sucrose was the lowest (0-1.54 g/100 g dw) detected sugar fraction. As an exception, sucrose was not determined in red currant 'Red Lake. The low sucrose content in Ribes fruits can potentially be linked to enzymatic hydrolysis after translocation from the leaves (Mikulic-Petkovsek et al., 2012). Rubinskiene et al. (2005) found sucrose content in black currant cultivars between $1.04-2.91 \mathrm{mg} / 100 \mathrm{~g} \mathrm{fw}$. These results were similar to our findings.

The mineral content of fruits are given in Table 1 . The K levels were dedected the most abundant element in all samples and the amount decreased with the order of $\mathrm{Ca}, \mathrm{Mg}, \mathrm{Fe}, \mathrm{Cu}, \mathrm{Zn}$ and $\mathrm{Mn}$, respectively. In the comparison of the concentration of minerals among Ribes varieties, differences were observed $(p \leq 0.01)$. Se was not detected in any species and $\mathrm{Na}$ was found only 'Goliath' variety. K levels ranged from $8,374.78 \mathrm{mg} / \mathrm{kg}$ to $10,803.95 \mathrm{mg} / \mathrm{kg} \mathrm{dw}$ in the samples. $\mathrm{K}$ was abundant in the Red Lake variety with the amount of $10,205.91 \mathrm{mg} / \mathrm{kg} \mathrm{dw}$. Plessi et al. (2007) reported that K concentration were $1,671.1 \mathrm{mg} / 100 \mathrm{~g} \mathrm{dw}$ in 'Red Lake' varieties. The highest value of $\mathrm{Ca}$ was found in 'Jostaberry' (1,815.45 mg/kg dw), followed by 'Boskoop Giant' $(1,673.22 \mathrm{mg} / \mathrm{kg} \mathrm{dw})$ and 'Rosenthal' (1,447.55 mg/kg dw). Similaly our results, Konić-Ristić et al. (2011) showed that the most abundant elements were $\mathrm{K}$, followed by $\mathrm{Ca}$ and $\mathrm{Mg}$ in black currant and red currant juice. $\mathrm{Mg}$ content ranged from $571.24 \mathrm{mg} / \mathrm{kg}$ to $684.63 \mathrm{mg} / \mathrm{kg} \mathrm{dw}$. The lowest content of $\mathrm{Mg}$ (571.24 mg/kg dw) was recorded in red currant (Red Lake). Plessi et al. (2007) found that Mg content in Red Lake variety was $97.63 \mathrm{mg} / 100 \mathrm{~g} \mathrm{dw}$, this result was higher than our findings. However, the highest Fe concentration was determined in 'Red Lake' (36.40 mg/kg dw) and 'Boskoop Giant' (33.46 mg/kg dw) varieties. Comparing with the literature, $\mathrm{Mn}, \mathrm{Cu}$ and $\mathrm{Zn}$ levels in Ribes species were lower from those obtained by Plessi et al. (1998) and Varo et al. (1980). According to results of mineral analyses, the investigated Ribes species were shown to be a potentially source of $\mathrm{K}, \mathrm{Ca}$ and $\mathrm{Mg}$ minerals as compared to other fruits.

Significant differences of ascorbic acid content were found among the different Ribes species tested (Table 1). However, 'Boskoop Giant' and 'Jostaberry' had similar amount of ascorbic acid. Black currant 'Rosenthal' variety had the highest content of ascorbic acid $(725.52 \mathrm{mg} / 100 \mathrm{~g} \mathrm{dw})$, while the lowest content was recorded in red currant 'Red Lake' ( $169.33 \mathrm{mg} / 100 \mathrm{~g} \mathrm{dw})$. Our results were close to those obtained by Pantelidis et al. (2007). Rubinskiene et al. (2005) showed that average amount of ascorbic acid varied from 112.3 to $220.5 \mathrm{mg} / 100 \mathrm{~g}$ fw in black currants, Mikulic-Petkovsek et al. (2016) reported that the ascorbic acid content ranged from 11.94 to $17.74 \mathrm{mg} / 100 \mathrm{~g}$ fw in red currants, 107.66 to $159.22 \mathrm{mg} / 100 \mathrm{~g} \mathrm{fw}$ in black currants and Szajdek \& Borowska, (2008) reported that blackcurrants are excellent sources of ascorbic acid, with an average content of $125-151 \mathrm{mg} / 100 \mathrm{~g} \mathrm{fw}$. These results were similar our findings ( $110.43-149.53 \mathrm{mg} / 100 \mathrm{~g} \mathrm{fw}$ ). In addition, according to our results, ascorbic acid content of black currants and 'Jostaberry' varieties were significantly higher than other fruits well known for their high ascorbic acid content, such as strawberries ( $46 \mathrm{mg} / 100 \mathrm{~g} \mathrm{fw}$ ) (Roberts \& Gordon, 2003), oranges ( $31 \mathrm{mg} / 100 \mathrm{~g} \mathrm{fw})$ (Roberts \& Gordon, 2003) and kiwi fruits (29-80 mg/ $100 \mathrm{~g} \mathrm{fw}$ ) (Nishiyama et al., 2004).

Adequate consumption of dietary fiber has been related to diverse nutritional and health benefits. High dietary fiber foods could offer important health benefits which can reduced the risk of type II diabetes, some cancers, cardiovascular disease and obesity (Zhang et al., 2018). Fruits and vegetables content in dietary fibers usually ranges from 1.0 to $5.4 \mathrm{~g}$ per $100 \mathrm{~g}$ of fresh weight (Septembre-Malaterre et al., 2018). SDF, IDF and TDF amount changed significantly in currant fruits (Table 1). Total dietary fibre levels were found between $7.17 \mathrm{~g} / 100 \mathrm{~g} \mathrm{dw}$ (Red Lake) and $9.90 \mathrm{~g} / 100 \mathrm{~g} \mathrm{dw}$ (Rosenthal). The total dietary fibre of the samples were contained $69 \%$ to $75 \%$ soluble fibre. Generally, total dietary fiber which obtained from fruit and vegetable contain a higher content of SDF. In total dietary fiber present insoluble-to-soluble fibre ratios in the range 1: 3 that are technologically desirable and therefore have superior functional properties (Alba et al., 2018). While, the content of soluble dietary fibre were in the range of 4.0 (Red Lake) to $7.23 \mathrm{~g} / 100 \mathrm{~g}$ (Rosenthal), the amount of insoluble dietary fibre were in the range of 2.06 (Jostaberry) to $3.16 \mathrm{~g} / 100 \mathrm{~g}$ (Red Lake) in currant berries. Pastell et al. (2019) reported that the IDF amount $5.44 \mathrm{~g} / 100 \mathrm{~g} \mathrm{fw}$, SDF $1.02 \mathrm{~g} / 100 \mathrm{~g}$ fw and TDF $6.46 \mathrm{~g} / 100 \mathrm{~g}$ fw in Finnish origin blackcurrant varieties. Our results were close to those obtained by Pastell et al. (2019), but higher than by Souza et al.(2014). These differences might be explained by variety properties, maturation, growing condition and differences values in air soil composition.

\subsection{Color analysis}

It is well-known that perfect colouration is a key factor of fruit acceptance by the consumers next to taste and aroma (Mikulic-Petkovsek et al., 2016). The color of currant berry varities are shown in Table 2. Significant differences in $\mathrm{L}^{*}, \mathrm{a}^{*}$ and $\mathrm{b}^{*}$ color values among the currant species were not recorded except for 
'Red Lake' variety. $L^{\star}$ value of 'Red Lake' is 32.88 , $a^{\star}$ value is 19.40 and $b^{\star}$ value is 8.04 . $a^{\star}$ value $(19,40)$ of red currant variety is higher than other varieties as expected. In a study carried out with red color berries, the $L^{*}$ values of red raspberry in range of 32.5-33.9, $\mathrm{a}^{\star}$ values in range of 24.9- 25.4 and $\mathrm{b}^{\star}$ values in range of 11.6- 11.9 (Giovanelli et al., 2014). Mikulic-Petkovsek et al. (2015) reported that during 2-4 weeks of ripening, the average $L^{*}$ values of black currants 11.85-18.07, 'Jostaberry' 19.05-31.77 and red currants in range of 24.28-45.1 in three maturity stages. In another study, Mikulic-Petkovsek et al. (2016) found that average $\mathrm{L}^{*}$ parameter of black currants ranged from 23.48 to 24.10 and of red currants from 28.74 to 29.36 . Our findings are in agreement with those results.

\subsection{Volatile organic compounds}

In general, the common volatile compounds that significantly contributed to the overall aroma and play a role in determining acceptability of all currant cultivars were ocimene, carene, alpha-phellandrene, alpha-terpinene, benzaldehyde and piperonal between the 125 volatile components investigated (Table 3). Methy butanoate, p-cymene, methyl butanoate, methyl decanoate, hexanal, nonanal, linalool, hexanoic acid, benzaldehyde, 3,4 dimethyl benzaldehyde, ethyl acetate and methyl benzoate are determined volatile organic compounds in different six blackcurrant cultivars by Liu et al. (2018). Ohlsson (2010) determined in black currant juices methyl butanoate, p-cymene, linalool, methyl benzoate compounds. Bagger-Jørgensen et al.

Table 2. Colorimetric parameters of currant varities.

\begin{tabular}{lrrrrr}
\hline & ROSENTHAL & RED LAKE & BOSKOOP G. & JOSTABERRY & GOLIATH \\
\hline $\mathbf{L}^{*}$ & $25.87 \pm 0.57^{\mathrm{b}}$ & $32.88 \pm 0.71^{\mathrm{a}}$ & $26.38 \pm 0.31^{\mathrm{b}}$ & $25.64 \pm 0.25^{\mathrm{b}}$ & $25.76 \pm 0.40^{\mathrm{b}}$ \\
$\mathbf{a}^{*}$ & $0.64 \pm 0.39^{\mathrm{b}}$ & $19.40 \pm 1.95^{\mathrm{a}}$ & $0.05 \pm 0.04^{\mathrm{b}}$ & $1.44 \pm 0.47^{\mathrm{b}}$ & $0.67 \pm 0.28^{\mathrm{b}}$ \\
$\mathbf{b}^{*}$ & $-1.03 \pm 0.47^{\mathrm{b}}$ & $8.04 \pm 1.02^{\mathrm{a}}$ & $-0.78 \pm 0.40^{\mathrm{b}}$ & $-0.45 \pm 0.16^{\mathrm{b}}$ & $-0.84 \pm 0.37^{\mathrm{b}}$ \\
\hline
\end{tabular}

Different letters in the same lines represent results with statistical difference, according to the Fisher's LSD test ( $\mathrm{p} \leq 0.01)$.

Table 3. Volatile organic compounds of currant varieties.

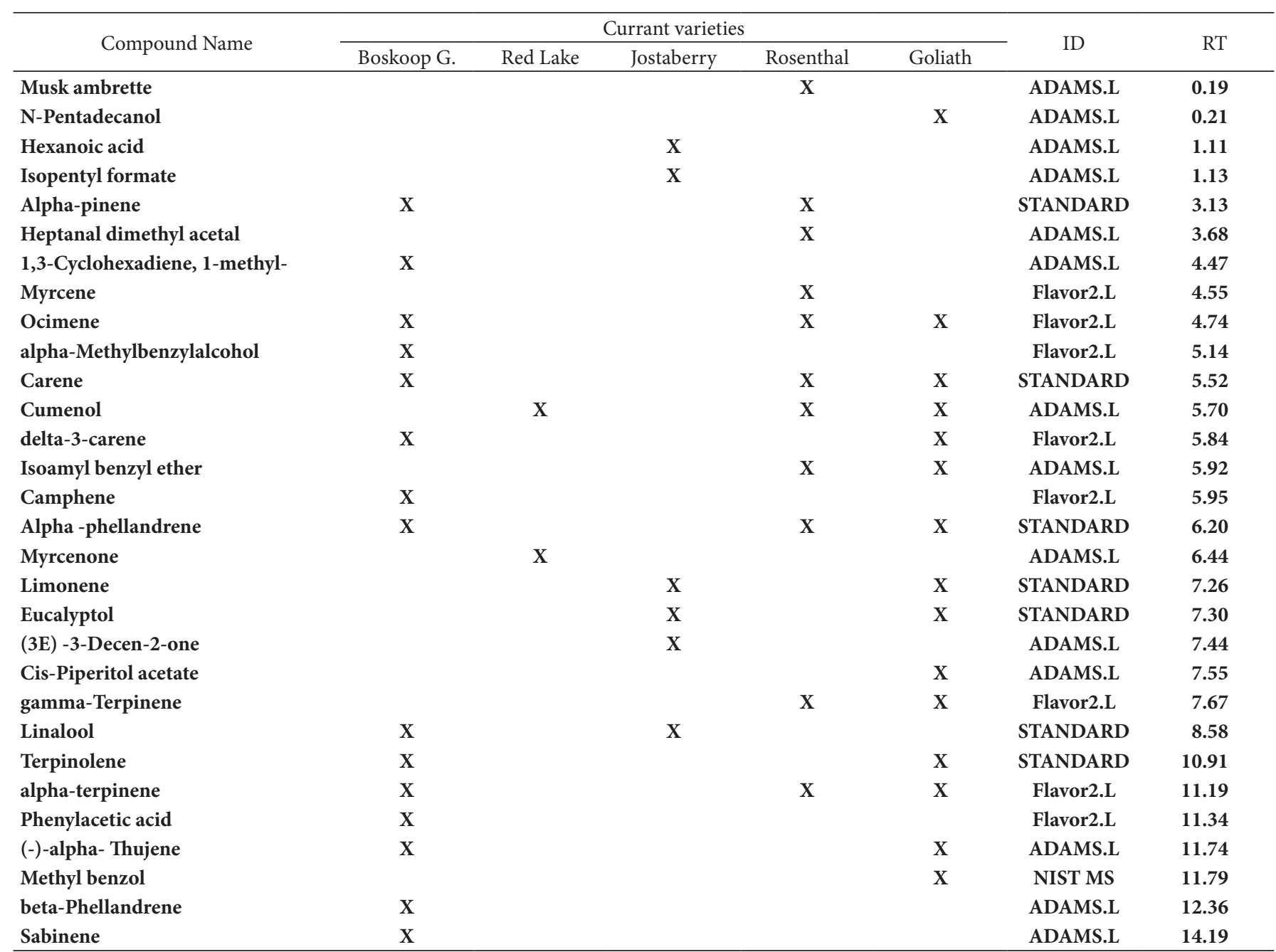

ID = Identification used as confirmation of compounds; RT = retention time. 
Table 3. Contined...

\begin{tabular}{|c|c|c|c|c|c|c|c|}
\hline \multirow{2}{*}{ Compound Name } & \multicolumn{5}{|c|}{ Currant varieties } & \multirow{2}{*}{ ID } & \multirow{2}{*}{ RT } \\
\hline & Boskoop G. & Red Lake & Jostaberry & Rosenthal & Goliath & & \\
\hline beta-Pinene & $\mathbf{X}$ & & & & & Flavor2.L & 14.85 \\
\hline Methyl octanoate & & & $\mathbf{X}$ & & & STANDARD & 16.88 \\
\hline Benzoin & $\mathbf{X}$ & & & $\mathbf{X}$ & & ADAMS.L & 18.08 \\
\hline Octyl formate & & & $\mathbf{X}$ & & & STANDARD & 18.92 \\
\hline Methyl 2-furoate & & $\mathbf{X}$ & & & & ADAMS.L & 21.52 \\
\hline 2 -çarene & & & & & $\mathbf{X}$ & NIST MS & 22.11 \\
\hline gamma-muurolene & & & & & $\mathbf{X}$ & NIST MS & 22.14 \\
\hline beta-Cubebene & & & & $\mathbf{X}$ & & ADAMS.L & 22.16 \\
\hline Benzalydehyde,3,4-dimethyl & & & & & $\mathbf{X}$ & NIST MS & 22.19 \\
\hline beta-Ylangene & & & & & $\mathbf{X}$ & ADAMS.L & 22.99 \\
\hline Methyl decanoate & & & & $\mathbf{X}$ & & STANDARD & 23.98 \\
\hline Hexyl hexanoate & $\mathbf{X}$ & & & $\mathbf{X}$ & & STANDARD & 24.03 \\
\hline Methyl benzoate & $\mathbf{X}$ & & & & & STANDARD & 24.80 \\
\hline Ethyl 3-(acetyloxy) butanoate & $\mathbf{X}$ & & & $\mathbf{X}$ & $\mathbf{X}$ & STANDARD & 24.88 \\
\hline 5-methyl Furfural & & $\mathbf{X}$ & & & & ADAMS.L & 25.58 \\
\hline 2- Methoxypyrazine & & $\mathbf{X}$ & & & & ADAMS.L & 25.65 \\
\hline Benzonitril & & & $\mathbf{X}$ & & & NIST MS & 26.18 \\
\hline Ethyl decanoate & & & & $\mathbf{X}$ & & STANDARD & 26.30 \\
\hline Methyl butanoate & & & & $\mathbf{X}$ & & ADAMS.L & 26.40 \\
\hline Furfural & $\mathbf{X}$ & $\mathbf{X}$ & & & & ADAMS.L & 31.98 \\
\hline Trans-Dihydrocarvone & $\mathbf{X}$ & & & & & ADAMS.L & 31.98 \\
\hline Citronellyl butyrate & $\mathbf{X}$ & & & & $\mathbf{X}$ & STANDARD & 32.06 \\
\hline Methylsalicylate & & & $\mathbf{X}$ & & & Flavor2.L & 32.15 \\
\hline Nerol & & & $\mathbf{X}$ & & & STANDARD & 32.21 \\
\hline Phenethyl formate & & & $\mathbf{X}$ & & & Flavor2.L & 33.29 \\
\hline Isopropyyl laurate & & & $\mathbf{X}$ & & & STANDARD & 34.40 \\
\hline Lauric acid,ethyl ester & & & $\mathbf{X}$ & & & NIST MS & 34.63 \\
\hline Pregnanne-3,5-diol & & & $\mathbf{X}$ & & & NIST MS & 34.81 \\
\hline Dodecanoic acid,ethyl ester & & & $\mathbf{X}$ & & & NIST MS & 35.00 \\
\hline Isoamyl benzyl ether & & & $\mathbf{X}$ & & & ADAMS.L & 36.21 \\
\hline Phenol & & $\mathbf{X}$ & $\mathbf{X}$ & & & Flavor2.L & 38.06 \\
\hline 2-Isobutyl-3-methoxypyrazine & & $\mathbf{X}$ & & & & ADAMS.L & 38.42 \\
\hline Orcinol & & $\mathbf{X}$ & & & & ADAMS.L & 38.49 \\
\hline Methyl-2-pyrrolyl ketone & & & $\mathbf{X}$ & & & Flavor2.L & 38.59 \\
\hline Tagetone & & $\mathbf{X}$ & & & & ADAMS.L & 38.98 \\
\hline Isopentyl salicylate & & & & $\mathbf{X}$ & & ADAMS.L & 46.82 \\
\hline Conglomerone & & & $\mathbf{X}$ & & & ADAMS.L & 47.89 \\
\hline 1-Decanol & & & & $\mathbf{X}$ & & Flavor2.L & 49.16 \\
\hline Phenylacetaldehyde & & $\mathbf{X}$ & & & & Flavor2.L & 49.52 \\
\hline
\end{tabular}

\footnotetext{
ID = Identification used as confirmation of compounds; RT = retention time.
} 
Table 3. Contined...

\begin{tabular}{|c|c|c|c|c|c|c|c|}
\hline \multirow{2}{*}{ Compound Name } & \multicolumn{5}{|c|}{ Currant varieties } & \multirow{2}{*}{ ID } & \multirow{2}{*}{ RT } \\
\hline & Boskoop G. & Red Lake & Jostaberry & Rosenthal & Goliath & & \\
\hline Salicylaldehyde & & $\mathrm{X}$ & & & & ADAMS.L & 50.28 \\
\hline Isobutyl benzoate & & $\mathbf{X}$ & & & & Flavor2.L & 50.30 \\
\hline Ethylbenzoate & & & $\mathbf{X}$ & $\mathbf{X}$ & & Flavor2.L & 50.36 \\
\hline 2-Phenylpropanal & & $\mathbf{X}$ & & & & ADAMS.L & 50.82 \\
\hline Cumene & & $\mathbf{X}$ & & & & ADAMS.L & 50.83 \\
\hline para-Methyl Acetophenone & & $\mathbf{X}$ & & & & ADAMS.L & 50.85 \\
\hline 4'-Methylacetophenone & & $\mathbf{X}$ & & & & Flavor2.L & 50.86 \\
\hline P-Cymene & & & & $\mathbf{X}$ & & ADAMS.L & 50.89 \\
\hline Benzophenone & & & $\mathbf{X}$ & & & ADAMS.L & 50.93 \\
\hline 2-Butylthiophene & & $\mathbf{X}$ & & $\mathbf{X}$ & & ADAMS.L & 51.60 \\
\hline Piperonal & $\mathbf{X}$ & $\mathbf{X}$ & $\mathbf{X}$ & $\mathbf{X}$ & & ADAMS.L & 51.91 \\
\hline Lauryl alcohol & & & & $\mathbf{X}$ & & Flavor2.L & 52.30 \\
\hline Octadecene & & & & $\mathbf{X}$ & & ADAMS.L & 52.79 \\
\hline Dodecanoic acid & & & & $\mathbf{X}$ & & ADAMS.L & 53.11 \\
\hline Ethyl laurate & & $\mathbf{X}$ & & & & Flavor2.L & 53.11 \\
\hline Butyrophenone & & $\mathbf{X}$ & & & & ADAMS.L & 53.31 \\
\hline Methyl dodecanoate & & $\mathbf{X}$ & & & & ADAMS.L & 53.84 \\
\hline Butanal, 2-methyl & & & $\mathbf{X}$ & & & NIST MS & 54.36 \\
\hline Ethyl tetradecanoate & & & & $\mathbf{X}$ & & ADAMS.L & 54.67 \\
\hline Isopropyl hexadecanoate & & $\mathbf{X}$ & & & & ADAMS.L & 54.67 \\
\hline 4-Methoxy cinnamic acid & & $\mathbf{X}$ & & & & ADAMS.L & 54.85 \\
\hline Cis-Pinane & & & & $\mathbf{X}$ & & ADAMS.L & 55.00 \\
\hline Cyclohexadecanolide & & $\mathbf{X}$ & & & & ADAMS.L & 55.01 \\
\hline Methyl butyl benzoate & & & & $\mathbf{X}$ & & ADAMS.L & 55.04 \\
\hline 4-Hydroxybenzaldehyde & & $\mathbf{X}$ & & & & ADAMS.L & 55.55 \\
\hline 2,3-Butanediol & & & $\mathbf{X}$ & & & NIST MS & 56.04 \\
\hline Anilin & & $\mathbf{X}$ & & & & NIST MS & 56.17 \\
\hline Cubitene & & & & $\mathbf{X}$ & & ADAMS.L & 56.21 \\
\hline p-Methylphenyl acetate & & & $\mathbf{X}$ & & & Flavor2.L & 56.21 \\
\hline Tagetone, (E)- & & $\mathbf{X}$ & & & & ADAMS.L & 56.22 \\
\hline Decanoic acid & & $\mathbf{X}$ & & & & ADAMS.L & 56.88 \\
\hline Methyl Eugenol & & $\mathbf{X}$ & & & & ADAMS.L & 57.57 \\
\hline 2- Butanol & & & & & $\mathbf{X}$ & NIST MS & 58.64 \\
\hline Acetalydehyde ethyl amyl acetal & & & $\mathbf{X}$ & & & NIST MS & 58.79 \\
\hline Trimethylamine & & & $\mathbf{X}$ & & & NIST MS & 59.23 \\
\hline Ethyl acetate & $\mathbf{X}$ & & & & & STANDARD & 59.41 \\
\hline Methylthiazole & & & $\mathbf{X}$ & & & NIST MS & 59.78 \\
\hline Seselin & & & & & $\mathbf{X}$ & ADAMS.L & 59.94 \\
\hline Pyruvic acid & & $\mathbf{X}$ & & & & ADAMS.L & 60.99 \\
\hline 3 methyl hexanoic acid & & & $\mathbf{X}$ & & & NIST MS & 61.57 \\
\hline
\end{tabular}

ID = Identification used as confirmation of compounds; RT = retention time.

(2004) determined methyl butanoate and furfural compounds in black currant juice produced from black currant 'Ben Lomond' variery. These results are in accordance with our findings. In this research, ethyl acetate is found in only black currant 'Boskoop Giant' but Boschetti et al. (1999) determined in red currant 'Roveda' variety. Ethyl acetate, $\beta$-pinene, $\beta$-myrcene, $\beta$-phellandrene, eucalyptol, $\alpha$-pinene, $\beta$-cymene, terpinolene, nonanal, benzaldehyde, methyl decanoate, methyl benzoate, citronellyl butyrate are the detected compounds in black currant varities, these compounds are also detected by Harb et al. (2008).

Principal component analysis (PCA) was performed evaluate the volatile organic compounds differences between
5 different currant cultivars. The composition of volatile organic compounds data obtained by GC-QTOF ESI-MS and the data were preprocessed prior to PCA analysis. All data were generated by triplicate experiments. As a result of the evaluation of the aroma profiles of the samples, 1157 different data were obtained. These complex data were reduced to 86 metabolites using various filters that could make a statistical difference. The 86 compounds detected in 5 currant cultivars were analyzed via PCA. The scatter plot of PCs scores of currant cultivars were shown in Figure 1. The first three principal components explained $79.04 \%$ of the total variation. The PC 1 explained $36.84 \%$ of the total variance, PC 2 explained $22.97 \%$ of total variance and PC 3 explained 


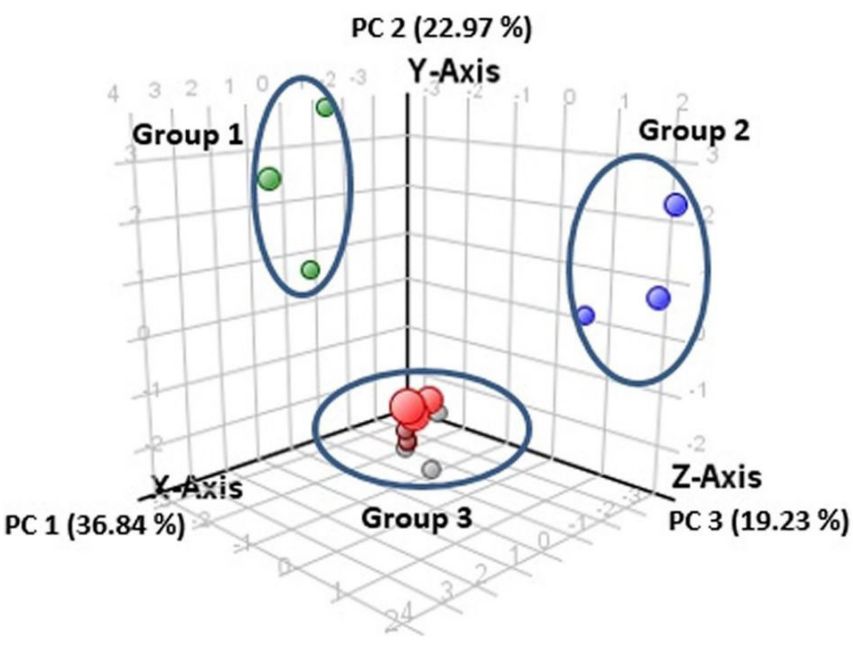

Figure 1. 3D PCA score plots of the data from GC-QTOF ESI-MS of currant varieties. Green, purple, red, brown and grey colors represent 'Rosenthal', 'Goliath', 'Boskoop Giant', 'Jostaberry' and 'Red lake', respectively.

$19.23 \%$ of the total variance. The 5 currant cultivar could be divided into three groups based on the relationships between cultivars and volatile organic compounds. Group 1 was on the positive side of PC 1 and negative side of PC 2 with the longest distance and contained 'Rosenthal' cultivar. Group 2 was on the positive side of PC 2 and PC 3 contained 'Goliath' cultivar and group 3, including 'Jostaberry', 'Red lake' and 'Boskoop giant' cultivars on the negative side of PC 1 and PC 3. PCA showed a relatively good separation of 'Rosenthal' and 'Goliath' variety using three dimensional principal components, so these two cultivars showed big differences in the volatile fraction that they can be differentiated in the PCA plot from each other. The three remaining cultivars 'Red lake, 'Jostabery' and 'Boskoop giant' showed a great similarity given by a close location in the PCA plot. These cultivars were distinguished from the 'Rosenthal' and 'Goliath' species, but there were no statistically differences in terms of the volatile components between each other. In conclusion, it was considered that the genetic background of the investigated currant cultivars had significant impacts on the chemical, nutritional and aroma composition of the berries.

\section{Conclusion}

The investigated Ribes species were shown to be a potentially source of $\mathrm{K}, \mathrm{Ca}$ and $\mathrm{Mg}$ minerals as compared to other fruits. Fiber, an important component with beneficial effects to organism, ranged from $7.16 \mathrm{~g} / 100 \mathrm{~g} \mathrm{dw}$ in 'Red lake' to $9.90 \mathrm{~g} / 100 \mathrm{~g} \mathrm{dw}$ in 'Rosenthal'. The amount of ascorbic acid of currant varieties were determined significantly higher than other fruits well known for their high ascorbic acid content. For this reason, currant fruits were considered an excellent source of vitamin $C$. The volatile compounds detected in all currant varieties were ocimene, carene, alpha-phellandrene, alpha-terpinene, benzaldehyde and piperonal' within the 125 investigated compounds. According to PCA, 'Rosenthal' and 'Goliath' cultivars showed big differences in the volatile fraction that they can be differentiated in the PCA plot from each other. In conclusion, it was considered that the genetic background of the investigated currant cultivars had significant impacts on the chemical, nutritional and aroma composition of the berries.

\section{Acknowledgements}

The authors would like to thank TAGEM (General Directorate of Agricultural Research and Policies, Turkey) for financially support this research project (Project No: 17/A03/P06/139). Additionally, thanks are given to Central Research Institute of Food and Feed Control for technical support. This study is a part of $\mathrm{PhD}$ thesis of the first author.

\section{References}

Alba, K., MacNaughtan, W., Laws, A. P., Foster, T. J., Campbell, G. M., \& Kontogiorgos, V. (2018). Fractionation and characterisation of dietary fibre from blackcurrant pomace. Food Hydrocolloids, 81, 398-408. http://dx.doi.org/10.1016/j.foodhyd.2018.03.023.

Association of Official Analytical Chemists - AOAC. (1994). Official methods of analysis of the Association of Official Analytical Chemists (Method 991.43). Arlington: AOAC.

Association of Official Analytical Chemists - AOAC. (2000a). Official methods of analysis of the Association of Official Analytical Chemists (Chap. 37, p. 11, Method 942.15). Arlington: AOAC.

Association of Official Analytical Chemists - AOAC. (2000b). Official methods of analysis of the Association of Official Analytical Chemists (Chap. 37, p. 7, Method 932.12). Arlington: AOAC.

Association of Official Analytical Chemists - AOAC. (2000c). Official methods of analysis of the Association of Official Analytical Chemists (Chap. 44, p. 27, Method 977.20). Arlington: AOAC.

Association of Official Analytical Chemists - AOAC. (2002). Official methods of analysis of the Association of Official Analytical Chemists (Chap. 4, p. 30-31, Method 990.03). Arlington: AOAC.

Bagger-Jørgensen, R., Meyer, A. S., Varming, C., \& Jonsson, G. (2004). Recovery of volatile aroma compounds from black currant juice by vacuum membrane distillation. Journal of Food Engineering, 64(1), 23-31. http://dx.doi.org/10.1016/j.jfoodeng.2003.09.009.

Baldwin, E. A. (2002). Fruit flavor, volatile metabolism and consumer perceptions. Boca Raton: CRC Press.

Bordonaba, J. G., \& Terry, L. A. (2008). Biochemical profiling and chemometric analysis of seventeen UK-Grown black currant cultivars. Journal of Agricultural and Food Chemistry, 56(16), 7422-7430. http://dx.doi.org/10.1021/jf8009377. PMid:18642846.

Boschetti, A., Biasioli, F., van Opbergen, M., Warneke, C., Jordan, A., Holzinger, R., Prazeller, P., Karl, T., Hansel, A., Lindinger, W., \& Iannotta, S. (1999). PTR-MS real time monitoring of the emission of volatile organic compounds during postharvest aging of berryfruit. Postharvest Biology and Technology, 17(3), 143-151. http://dx.doi. org/10.1016/S0925-5214(99)00052-6.

Burak, M., \& Güngör, M. K. (2001). Sekizinci beş yillik kalkinma plani. Ankara: Bitkisel Üretim Özel İhtisas Komisyonu. Meyvecilik Alt Komisyon Raporu.

Christensen, L. P., \& Pedersen, H. L. (2006). Varietal differences in the aroma compound profile of blackcurrant berries. Developments in Food Science, 43, 257-260. http://dx.doi.org/10.1016/S01674501(06)80061-0.

Contessa, C., Mellano, M. G., Beccaro, G. L., Giusiano, A., \& Botta, R. (2013). Total antioxidant capacity and total phenolic and 
anthocyanin contents in fruit species grown in Northwest Italy-. Scientia Horticulturae, 160, 351-357. http://dx.doi.org/10.1016/j. scienta.2013.06.019.

Fu, Y., Zhou, X., Chen, S., Sun, Y., Shen, Y., \& Ye, X. (2015). Chemical composition and antioxidant activity of Chinese wild raspberry (Rubus hirsutus Thunb.). Lebensmittel-Wissenschaft + Technologie, 60(2), 1262-1268. http://dx.doi.org/10.1016/j.lwt.2014.09.002.

Garcia, C. V., Quek, S. Y., Stevenson, R. J., \& Winz, R. A. (2012). Characterisation of bound volatile compounds of a low flavour kiwifruit species: Actinidia eriantha. Food Chemistry, 134(2), 655-661. http://dx.doi.org/10.1016/j.foodchem.2012.02.148. PMid:23107675.

Giovanelli, G., Limbo, S., \& Buratti, S. (2014). Effects of new packaging solutions on physico-chemical, nutritionaland aromatic characteristics of red raspberries (Rubus idaeus L.) inpostharvest storage. Postharvest Biology and Technology, 98, 72-81. http://dx.doi.org/10.1016/j. postharvbio.2014.07.002.

Gökmen, V., Kahraman, N., Demir, N., \& Acar, J. (2000). Enzymatically validated liquid chromotographic method for the determination of ascorbic acid and dehydroascorbic acids in fruit and vegetables. Journal of Chromatography. A, 881(1-2), 309-316. http://dx.doi. org/10.1016/S0021-9673(00)00080-7. PMid:10905714.

Harb, J., Bisharat, R., \& Streif, J. (2008). Changes in volatile constituents of blackcurrants (Ribes nigrum L. cv. 'Titania') following controlled atmosphere storage. Postharvest Biology and Technology, 47(3), 271279. http://dx.doi.org/10.1016/j.postharvbio.2007.08.007.

Hollands, W., Brett, G. M., Radreau, P., Saha, S., Teucher, B., Bennett, R. N., \& Kroon, P. A. (2008). Processing blackcurrants dramatically reduces the content and does not enhance the urinary yield of anthocyanins in human subjects. Food Chemistry, 10(3), 869-878. http://dx.doi.org/10.1016/j.foodchem.2007.11.052. PMid:26065747.

Kampuss, K., Christensen, L. P., \& Lindhard Pedersen, H. (2008). Volatile composition of blackcurrant cultivars. Acta Horticulturae, (777), 525-529. http://dx.doi.org/10.17660/ActaHortic.2008.777.81.

Konica Minolta. (2013). Precise colour communication: colour control from feelig to instrumentation. Osaka: Minolta Camera Co.

Konić-Ristić, A., Šavikin, K., Zdunić, G., Janković, T., Juranic, Z., Menković, N., \& Stanković, I. (2011). Biological activity and chemical composition of different berry juices. Food Chemistry, 125(4), 14121417. http://dx.doi.org/10.1016/j.foodchem.2010.10.018.

Liu, Y., Wang, S., Ren, J., Yuan, G., Li, Y., Zhang, B., \& Zhu, B. (2018). Characterization of free and bound volatile compounds in six Ribes nigrum L. blackcurrant cultivars. Food Research International, 103, 301-315. http://dx.doi.org/10.1016/j.foodres.2017.10.038. PMid:29389620.

Mattila, P. H., Hellström, J., Karhu, S., Pihlava, J. M., \& Veteläinen, M. (2016). High variability in flavonoid contents and composition between different North-European currant (Ribes spp.) varieties. Food Chemistry, 204, 14-20. http://dx.doi.org/10.1016/j.foodchem.2016.02.056. PMid:26988470.

Mikkonen, T. P., Määttä, K. R., Hukkanen, A. T., Kokko, H. I., Törrönen, A. R., Kärenlampi, S. O., \& Karjalainen, R. O. (2001). Flavonol Content Varies Among Black Currant Cultivars. Journal of Agricultural and Food Chemistry, 49(7), 3274-3277. http://dx.doi.org/10.1021/ jf0010228. PMid:11453762.

Mikulic-Petkovsek, M., Koron, D., \& Veberic, R. (2016). Quality parameters of currant berries from three different clusterpositions. Scientia Horticulturae, 210, 188-196. http://dx.doi.org/10.1016/j. scienta.2016.07.030.

Mikulic-Petkovsek, M., Rescic, J., Schmitzer, V., Stampar, F., Slatnar, A., Koron, D., \& Veberic, R. (2015). Changes in fruit quality parameters of four Ribes species during ripening. Food Chemistry, 173, 363-374. http://dx.doi.org/10.1016/j.foodchem.2014.10.011. PMid:25466034.

Mikulic-Petkovsek, M., Schmitzer, V., Slatnar, A., Stampar, F., \& Veberic, R. (2012). Composition of sugars, organic acids, and total phenolics in 25 wild or cultivated berry species. Journal of Food Science, 77(10), C1064-C1070. http://dx.doi.org/10.1111/j.1750-3841.2012.02896.x. PMid:22924969.

Nishiyama, I., Yamashita, Y., Yamanaka, M., Shimohashi, A., Fukuda, T., \& Oota, T. (2004). Varietal difference in vitamin C content in the fruit of kiwifruit and other Actinidia species. Journal of Agricultural and Food Chemistry, 52(17), 5472-5475. http://dx.doi.org/10.1021/ jf049398z. PMid:15315387.

Nordic Committee on Food Analysis - NMKL. (2007). Trace elementsdetermination by ICP-MS after pressure digestion (No. 186). Denmark: NMKL.

Ohlsson, A. (2010). Comparison of flavour compounds in juices from different blackcurrant varieties. Kalmar: School of Pure and Applied Natural Sciences, University of Kalmar. Examination Project Work $30 \mathrm{hp}$.

Pantelidis, G. E., Vasilakakis, M., Manganaris, G. A., \& Diamantidis, G. (2007). Antioxidant capacity, phenol, anthocyanin and ascorbic acid contents in raspberries, blackberries, red currants, gooseberries and Cornelian cherries. Food Chemistry, 102(3), 777-783. http:// dx.doi.org/10.1016/j.foodchem.2006.06.021.

Pastell, H., Putkonen, T., \& Rita, H. (2019). Dietary fibre in legumes, seeds, vegetables, fruits and mushrooms: Comparing traditional and semi-automated filtration techniques. Journal of Food Composition and Analysis, 75, 1-7. http://dx.doi.org/10.1016/j.jfca.2018.09.011.

Piry, J., \& Pribela, A. (1994). Application of high-performance liquid chromatography to the analysis of the complex volatile mixture of black currant buds (ribes nigrum 1.). Journal of Chromatography. A, 665(1), 105-109. http://dx.doi.org/10.1016/0021-9673(94)87037-3.

Plessi, M., Bertelli, D., \& Albasini, A. (2007). Distribution of metals and phenolic compounds as a criterion to evaluate variety of berries and related jams. Food Chemistry, 100(1), 419-442. http://dx.doi. org/10.1016/j.foodchem.2005.09.018.

Plessi, M., Bertelli, D., Rastelli, G., Albasini, A., \& Monzani, A. (1998). Fruits of ribes, rubus, vaccinium, and prunus genus. Metal contents and genome. Fresenius' Journal of Analytical Chemistry, 361(4), 353-354. http://dx.doi.org/10.1007/s002160050902.

Roberts, W. G., \& Gordon, M. H. (2003). Determination of the total antioxidant activity of fruit and vegetables by a liposome assay. Journal of Agricultural and Food Chemistry, 51(5), 1486-1493. http:// dx.doi.org/10.1021/jf025983t. PMid:12590503.

Rubinskiene, M., Viskelis, P., Jasutiene, I., Viskeliene, R., \& Bobinas, C. (2005). Impact of various factors on the composition and stability of black currant anthocyanins. Food Research International, 38(8-9), 867-871. http://dx.doi.org/10.1016/j.foodres.2005.02.027.

Septembre-Malaterre, A., Remize, F., \& Poucheret, P. (2018). Fruits and vegetables, as a source of nutritional compounds and phytochemicals: Changes in bioactive compounds during lactic fermentation. Food Research International, 104, 86-99. http://dx.doi.org/10.1016/j. foodres.2017.09.031. PMid:29433787.

Souza, V. R., Pereira, P. A. P., Silva, Y. L. T., Oliveira Lima, L. C., Pio, R., \& Queiroz, F. (2014). Determination of the bioactive compounds, antioxidant activity and chemical composition of Brazilian blackberry, red raspberry, strawberry, blueberry and sweet cherry fruits. Food Chemistry, 156, 362-368. http://dx.doi.org/10.1016/j. foodchem.2014.01.125. PMid:24629981. 
Stewart, K. (1996). Processing in cranberry, blueberry, currant, and gooseberry. In L. Somogyi, D. Barrett \& Y. Hui (Eds.), Processing fruits: science and technology (Vol. 2: Major Processed Products, pp. 159-195). Lancaster: Technomic Publishing.

Szajdek, A., \& Borowska, E. (2008). Bioactive compounds and healthpromoting properties of berry fruits: a review. Plant Foods for Human Nutrition (Dordrecht, Netherlands), 63(4), 147-156. http://dx.doi. org/10.1007/s11130-008-0097-5. PMid:18931913.

TSE. (1998). TS 1129 ISO 1026: Fruit and vegetable products-Determination of dry matter content by drying under reduced pressure and water content by azeotropik distilation. Ankara: TSE.

TSE. (2001). TS 1728 ISO 1842: Meyve Sebze Ürünleri -pH Tayini. Ankara: TSE.

Varming, C., Andersen, M. L., \& Poll, L. (2006). Volatile monoterpenes in black currant (ribes nigrum L.) juice: Effects of heating and enzymatic treatment by b-glucosidase. Journal of Agricultural and Food Chemistry, 54(6), 2298-2302. http://dx.doi.org/10.1021/ jf051938k. PMid:16536610.

Varming, C., Petersen, M. A., \& Poll, L. (2004). Comparison of isolation methods for the determination of important aroma compounds in black currant (Ribes Nigrum L.) juice, using nasal impact frequency profiling. Journal of Agricultural and Food Chemistry, 52(6), 16471652. http://dx.doi.org/10.1021/jf035133t. PMid:15030225.

Varo, P., Lahelma, M., Nuurtamo, M., Saari, E., \& Koivistoinen, P. (1980). Mineral element composition of Finnish foods. VII. Potato, vegetables, fruits, berries, nuts and mushrooms. Acta Agriculturae Scandinavica (Suppl. 22), 89-113.

Villatoro, C., Altisent, R., Echeverría, G., Graell, J., López, M. L., \& Lara, I. (2008). Changes in biosynthesis of aroma volatile compounds during on-tree maturation of 'Pink Lady ${ }^{\circledR 3}$ apples. Postharvest Biology and Technology, 47(3), 286-295. http://dx.doi.org/10.1016/j. postharvbio.2007.07.003.

Woznicki, T. L., Heide, O. M., Sønsteby, A., Wold, A. B., \& Remberg, S. F. (2015). Effects of controlled post-flowering temperature and daylength onchemical composition of four black currant (Ribes nigrum L.) cultivarsof contrasting origin. Scientia Horticulturae, 19, 627-636. http://dx.doi.org/10.1016/j.scienta.2015.10.026.

Zhang, H., Wang, H., Cao, X., \& Wang, J. (2018). Preparation and modification of high dietary fiber flour: A review. Food Research International, 113, 24-35. http://dx.doi.org/10.1016/j.foodres.2018.06.068. PMid:30195518. 